Version définitive du manuscrit publiée dans / Final version of the manuscript published in :

Acta Horticulturae (2012), Vol. 957, p. 191-196

4. International Symposium on Models for Plant Growth, Environmental Control and Farm Management in

Protected Cultivation (HortiModel), Nov 04-08 2012, Nanjing China

\title{
A model of fruit growth integrating cell division and expansion processes
}

\author{
V. Baldazzi, N. Bertin and M. Génard \\ INRA, UR 1115 Plantes et Systèmes de Culture Horticoles, Domaine St Paul, Site \\ Agroparc, F-84941 Avignon Cedex 9, France
}

Keywords: fruit development, cell division, cell expansion, water and carbon fluxes, model, tomato.

\begin{abstract}
The development of a new organ is the results of coordinated events of cell division and expansion. Fruit growth starts immediately after bloom with intensive cell division. As development proceeds, the proliferative activity of cells progressively slows down giving way to a phase of pure cell enlargement, during fruit growth and ripening. Modeling the way cell division and expansion progress together is crucial to understand the emergence of specific morphological traits (fruit size, weight, shape and texture) and their dependence on environmental factors. Models already exist for cell division and late fruit growth (cell expansion), but the coupling of the two processes have not been addressed yet in fruit. Here we propose a first integrated model of tomato fruit development, explicitly coupling cell proliferation and expansion. The model is used to predict the evolution of cell number, size and ages during fruit development, under different environmental conditions.
\end{abstract}

\section{INTRODUCTION}

The final form and size of a tissue or organ result from the coordination of cell proliferation, expansion and differentiation patterns. These patterns have been largely described in leaf blades (Horiguchi et al., 2006; Asl et al., 2011) or in petals (Reale et al., 2002) that is for flat and thin structures. In fruit, although the physiological mechanisms behind each basic process (division or expansion) have been partly uncovered, little is known about the control of their spatial and temporal coordination. Despite, conflicting viewpoints, which have been formalized in the cellular, organismal and compensatory theories (Beemster et al., 2003; Tsukaya, 2003), it is admitted that organogenesis cannot be fully understood if organs are seen as a mere collection of single cells (Tsukaya and Beemster, 2006). Thus, investigating interactions between cell division and expansion is an important issue for the control of fruit growth.

Models are powerful tools to integrate biological knowledge and understand interactions among processes within complex structure (Génard et al., 2007). The cellular level should form the cornerstone for mechanistic modeling of plant organ growth, which will further allow integrating the output of molecular regulatory networks to cell division 
Version définitive du manuscrit publiée dans / Final version of the manuscript published in :

Acta Horticulturae (2012), Vol. 957, p. 191-196

4. International Symposium on Models for Plant Growth, Environmental Control and Farm Management in Protected Cultivation (HortiModel), Nov 04-08 2012, Nanjing China

and cell expansion processes (De Vos et al., 2012). Therefore, modeling the way cell division and expansion progress together is crucial to understand the emergence of specific morphological traits (fruit size, weight, shape and texture) and their dependence on environmental and genetic factors. Such a model has been recently proposed for Arabidopsis leaf epidermal cells (Asl et al., 2011). For fruits, models already exist for cell division (Dale, 1976, Thornley, 1981, Bertin et al., 2003, Bertin et al., 2007) and late fruit growth (cell expansion) (Fishman and Génard, 1998, Liu et al., 2007 ), but the coupling of the two processes have not been addressed yet. This was the objective of the present work.

\section{MATERIALS AND METHODS}

\section{Cell Division Model}

A deterministic model has been developed to predict the dynamic of cell population in the tomato fruit pericarp (Fishman et al., 2002; Bertin et al., 2003). This model considers a succession of division steps together with a progressive decline of the proliferative activity. So the early phase of intensive divisions is followed by a phase where both division and expansion occur simultaneously until the proliferative activity tends to zero and all cells expand. The decrease in cell proliferative activity occurs before anthesis as observed in young fruit (Bertin et al., 2007). The model includes 3 parameters: 1) the time at which the proliferative activity declines; 2) its rate of decrease; 3) the duration of the cell cycle.

\section{Cell Expansion Model}

Cell expansion is related to processes driving the fluxes of water and solutes into the expanding fruit tissues, including transport through the pedicel and epidermis, phloem unloading and the regulation of cell osmotic and hydrostatic pressures and cell wall biorheological properties (Cosgrove, 1993; Boyer \& Silk, 2004). This complexity has been integrated in the Fishman \& Génard (1998) model developed for peach fruit, assuming that fruit mesocarp behaves as a single cell. Tissue expansion is related to mesocarp turgor pressure and cell wall bio-rheological properties through the Lockhart equation (Lockhart, 1965). The total uptake of carbon from phloem is the sum of contributions from mass flow, passive diffusion, and active or facilitated transport, the last being represented by a Michaelis-Menten function with a term of non competitive inhibition to 
Version définitive du manuscrit publiée dans / Final version of the manuscript published in :

Acta Horticulturae (2012), Vol. 957, p. 191-196

4. International Symposium on Models for Plant Growth, Environmental Control and Farm Management in

Protected Cultivation (HortiModel), Nov 04-08 2012, Nanjing China

account for the decrease of carbon uptake with fruit age. This model has been successfully adapted to other species, including tomato (Liu et al., 2007).

\section{Integrated Cell Division and Expansion model}

The integrated model starts at the end of the pure division phase $(\mathrm{t}=0)$, once proliferating activity of the cells starts to decline and the expansion phase begins.

The fruit is described as a collection of cells populations, each one having a specific age and volume.

The number, age (birth date) and physiological state (proliferating or growing cells) of each population is predicted by the cell division model. Accordingly, the fraction of proliferating cells declines during development and cell division stops completely at the onset of fruit maturity. The initial number of cells is $\mathrm{N}(0)=n$ and the initial volume $\mathrm{V}(0)=n v 0$.

At any time, cells leaving the proliferating phase start to grow according to the cell growth model, starting from an initial volume $2 v 0$.

The rate of growth is therefore dependent on environmental conditions, giving rise to different cells size distribution according to the environment and/or applied agricultural practices. In this first version of the model, variability in the cell cycle duration is not taken into consideration.

\section{Model Parameterization and In Silico Simulations}

Most parameters values were taken from previous models (Bertin et al. 2003, Liu et al., 2007) . Nonetheless a few modifications had to be applied to account for cells competition for external resources. In particular, membrane conductivity of individual cells for water and sugar has been reduced in order to correctly reproduce the surface ratio between the whole fruit and the phloem. Time-dependent functions have also to be partially re-parametrized to account for the early phase of tomato fruit development.

We use environmental conditions registered in Avignon during spring 2006 as standard condition of growth. Water stress is simulated by decreasing the stem water potential by a constant amount of -4 bar with respect to standard values. Carbon stress is virtually 
Version définitive du manuscrit publiée dans / Final version of the manuscript published in :

Acta Horticulturae (2012), Vol. 957, p. 191-196

4. International Symposium on Models for Plant Growth, Environmental Control and Farm Management in

Protected Cultivation (HortiModel), Nov 04-08 2012, Nanjing China

applied by reducing the phloem carbon concentration by $25 \%$. Both carbon and water stress are applied continuously, since the beginning of the simulation.

\section{RESULTS}

\section{Tomato Growth and Cells Distribution}

Under normal conditions, the integrated model predicts a fruit fresh mass of $120 \mathrm{~g}$, a dry mass of $6.5 \mathrm{~g}$ (Fig.1, top) and a total number of cells. Fruit growth has the typical sigmoid shape with a rapid increase in fruit mass between 20 and 40 days. A plateau is reached after 40 days when growth slows down and cells proliferating activity is completely stopped (Fig.1, bottom). The corresponding cells distribution at maturity shows a high peak at small cells surface followed by a long tail that extends up to 1.4 $\mathrm{mm} 2$ (Fig. 2, left panel). As intuitively expected, older cells correspond to the larger ones, with a rapid decay of cells size over time (Fig 2, right)

\section{In Silico Analysis of Changes in Cells Distribution under Carbon and Water Stress}

The application of a continuous water stress strongly affects the growth of tomato fruits. Indeed, the fruit results smaller (fresh mass $19 \mathrm{~g}$ ) with an increased dry mass content (9\%) with respect to the control case (5\%). Differences in fruit volume are due to an overall reduction of cells growth: cells distribution is shrunk towards smaller values, with all cells having surfaces below $0.1 \mathrm{~mm} 2$ (Fig 3, left).

However, not all cells population are equally affected : in the water stress case, the surface vs birth-time plot is no more monotonic with time i.e. final cells surface is no longer an indicator of cells age. Instead, cells born before 10 days shows a constant volume, suggesting a different stress sensitivity in early developmental stages (Fig3, right).

The impact of carbon stress on cells distribution is less marked. The resulting fruit fresh mass is comparable to the water stress case but the global shape of the distribution stays almost unchanged (Fig.4). Indeed, whereas water stress seems to affect the tail of the distribution, variations of fruit size in the carbon-stress case are mainly due to a rearrangement of cells within the "heart" of the distribution. Under carbon-stress case, the number middle-size cells is reduced in favor of smaller cells (less than $0.01 \mathrm{~mm} 2$ ), that now account for more than half of the total cells number.

\section{DISCUSSION AND CONCLUSIONS}


Version définitive du manuscrit publiée dans / Final version of the manuscript published in :

Acta Horticulturae (2012), Vol. 957, p. 191-196

4. International Symposium on Models for Plant Growth, Environmental Control and Farm Management in Protected Cultivation (HortiModel), Nov 04-08 2012, Nanjing China

This paper presents a first integrated model of tomato fruit growth, explicitly including both the cell division and expansion phases. In particular our model takes into account the effect of environmental factors on cells growth, providing an original tool to investigate the relationship between cells division and expansion by looking at the corresponding cells distribution under different environments. In spite of quite a number of studies, indeed, the mutual regulation between cell expansion and cell division and their respective role in the resulting organ growth is still unclear. As a first step, a division-driven perspective has been assumed here: accordingly, cell division acts as a timer, that controls the temporal evolution of cells number, independently from environmental factors. A recent paper on leaves growth seems to support this view (Asl et al. 2011).

However, the reverse perspective of an expansion-driven mechanisms can not be ruled out, especially during the proliferation phase (Beemster et al., 2006) . Perspectives of this work thus include the test of a reverse coupling approach, in which cell division is controlled by the cell growth model. This would result in particular into variable and environment-dependent cell cycle duration. Hopefully, comparison between experimental data and model simulations, under different environmental scenarios, will help to elucidate the complex relationship between cell division and expansion.

\section{ACKNOWLEDGEMENTS}

This work has been partly supported by the European project Eranet Erasysbio+ FRIM.

\section{Literature cited}

Asl, LK, Dhondt, S, Boudolf, V, Beemster, GT, Beeckman, T, Inzé, D, Govaerts, W, De Veylder, L. 2011. Model-based analysis of Arabidopsis leaf epidermal cells reveals distinct division and expansion patterns for pavement and guard cells. Plant Physiol. 156: $2172-83$.

Beemster, GTS, Fiorani, F, Inzé, D. 2003. Cell cycle: the key to plant growth control? Trends Plant Sci. 8: 154-158.

Beemster, GTS, Vercruysse, S, De Veylder, L, Kuiper, M, Inzé, D. 2006. The Arabidopsis leaf as a model system for investigating the role of cell cycle regulation in organ growth. J.Plant Res.119: 43-50.

Bertin, N, Fishman, S, Génard, M. 2003. A model for early stage of tomato fruit development: cell multiplication and cessation of the cell proliferative activity. Ann Bot-London 92, 65-72.

Bertin, N., Lecomte, A., Brunel, B., Fishman, S., Génard, M. 2007. A model describing cell polyploidization in tissues of growing fruit as related to cessation of cell proliferation. J. Exp. Bot.58: 1003-1013.

Boyer, JS, Silk, WK. 2004. Hydraulics of plant growth. Funct. Plant Biol. 31: 761-773 
Version définitive du manuscrit publiée dans / Final version of the manuscript published in :

Acta Horticulturae (2012), Vol. 957, p. 191-196

4. International Symposium on Models for Plant Growth, Environmental Control and Farm Management in Protected Cultivation (HortiModel), Nov 04-08 2012, Nanjing China

Cosgrove, DJ. 1993. Water uptake by growing cells: an assessment of the controlling roles of wall relaxation, solute uptake, and hydraulic conductance. Int. J. Plant Sci. 154: 10-21.

Dale, JE. 1976. Cell division in leaves, pp.315-348 in Cell Division in Higher Plants. Ed. by M. M. Yeoman. Academic Press, London.

De Vos, D, Dzhurakhalov, A., Draelants, D. et al. 2012. Towards mechanistic models of plant organ growth. J. Exp. Bot. doi: 10.1093/jxb/ers037

Fishman, S, Génard, M. 1998. A biophysical model of fruit growth: simulation of seasonal and diurnal dynamics of mass. Plant, Cell and Environment 21, 739-752.

Fishman, S, Bertin, N, Génard, M. 2002. Cell Division and Cessation of Cell Proliferation in Growing Fruit. Acta Hort. 584: 125-131.

Génard, M, et al. 2007. Towards a virtual fruit focusing on quality: modelling features and potential uses. J. Exp. Bot. 58: 917-928.

Horiguchi, G, Ferjani, A, Fujikura, U, Tsukaya, H. 2006. Coordination of cell proliferation and cell expansion in the control of leaf size in Arabidopsis thaliana. $\mathrm{J}$ Plant Res. 119: 37-42.

Kheibarshekan, L, Asl, LK, Dhondt, S, Boudolf, V, Beemster, GTS, Beeckman, T, Inzé, D, Govaerts, W, De Veylder, L. 2011. Model-Based Analysis of Arabidopsis Leaf Epidermal Cells Reveals Distinct Division and Expansion Patterns for Pavement and Guard Cells. Plant Physiol 156: 2172-2183.

Liu, H-F., Génard, M., Guichard, S., Bertin, N. (2007). Model-assisted analysis of tomato fruit in relation to carbon and water fluxes. J. Exp. Bot. 58, 3567-3580.

Lockhart,JA. 1965. An analysis of irreversible plant cell elongation. J. Theor. Biol. 8: 264-276

Reale, L, Porceddu, A, Lanfaloni, L, et al. 2002. Patterns of cell division and expansion in developing petals of Petunia hybrid. Sex Plant Reprod15: 123-132.

Steudle, E. 2000. Water uptake by roots: effects of water deficit. J. Exp. Bot. 51: 15311542.

Thornley, J.H.M. 1981. Organogenesis. In: Rose DA. and Charles-Edwards DA. (eds). Mathematics and Plant Physiology. Academic Press, London. 49-65.

Tsukaya, H. 2003. Organ shape and size: a lesson from studies of leaf morphogenesis. Curr. Opin. Plant. Biol. 6: 57-62.

Tsukaya, H, Beemster, GTS. 2006. Genetics, cell cycle and cell expansion in organogenesis in plants. J. Plant Res. 119: 1-4. 
Version définitive du manuscrit publiée dans / Final version of the manuscript published in :

Acta Horticulturae (2012), Vol. 957, p. 191-196

4. International Symposium on Models for Plant Growth, Environmental Control and Farm Management in Protected Cultivation (HortiModel), Nov 04-08 2012, Nanjing China
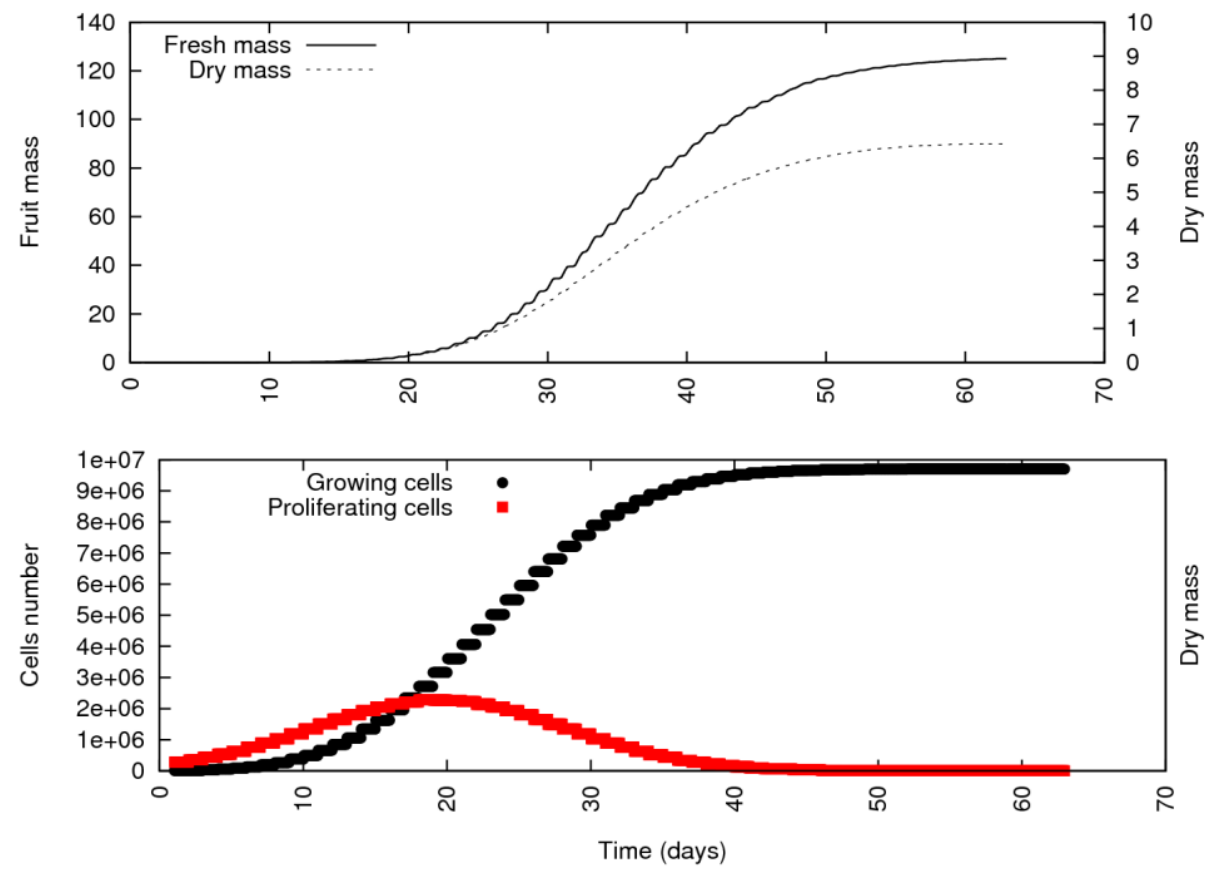

Figure 1: Tomato fruit growth under normal conditions. Top: Temporal evolution of fruit fresh and dry mass. Bottom: Temporal evolution of growing and proliferating cells populations.
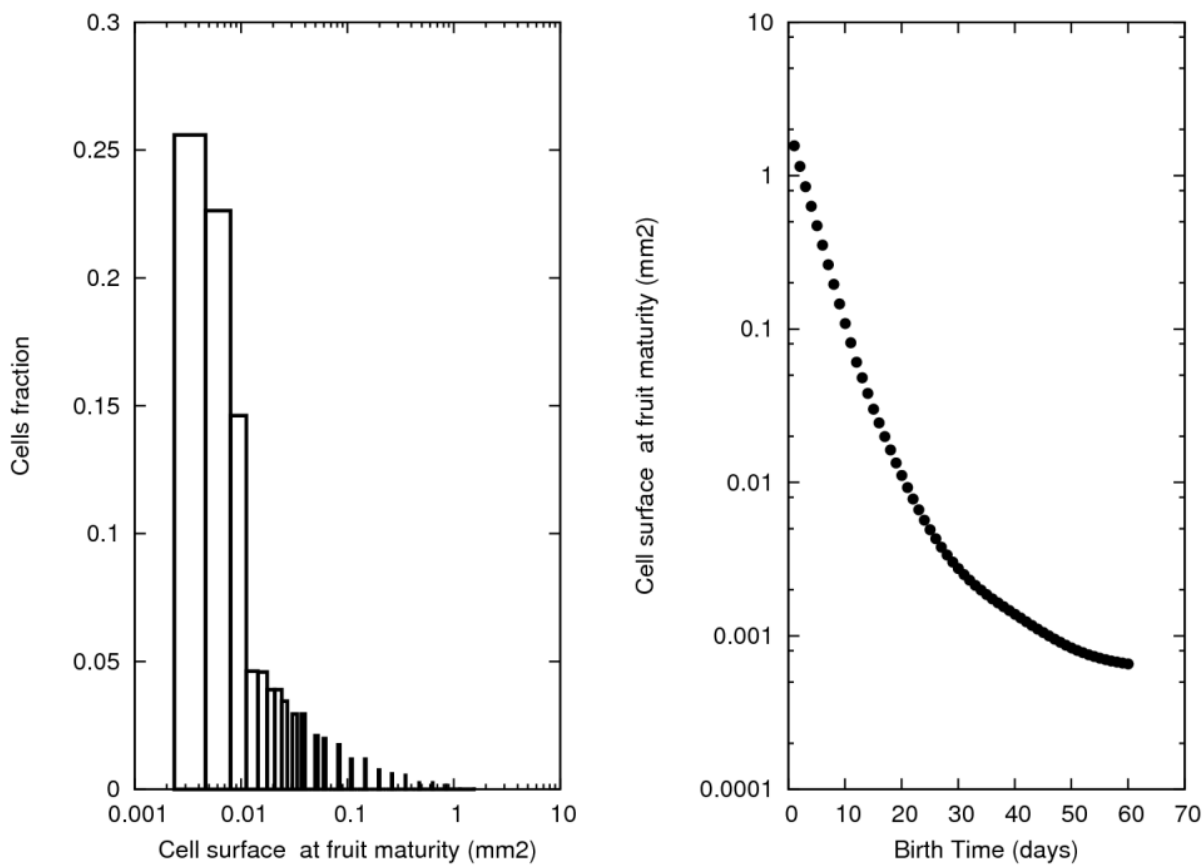

Comment citer ce document : 
Version définitive du manuscrit publiée dans / Final version of the manuscript published in :

Acta Horticulturae (2012), Vol. 957, p. 191-196

4. International Symposium on Models for Plant Growth, Environmental Control and Farm Management in Protected Cultivation (HortiModel), Nov 04-08 2012, Nanjing China

Figure 2: Cells distribution at fruit maturity under normal conditions. Left: distribution of cells surfaces at fruit maturity. Most cells have a small surface (below 0.01
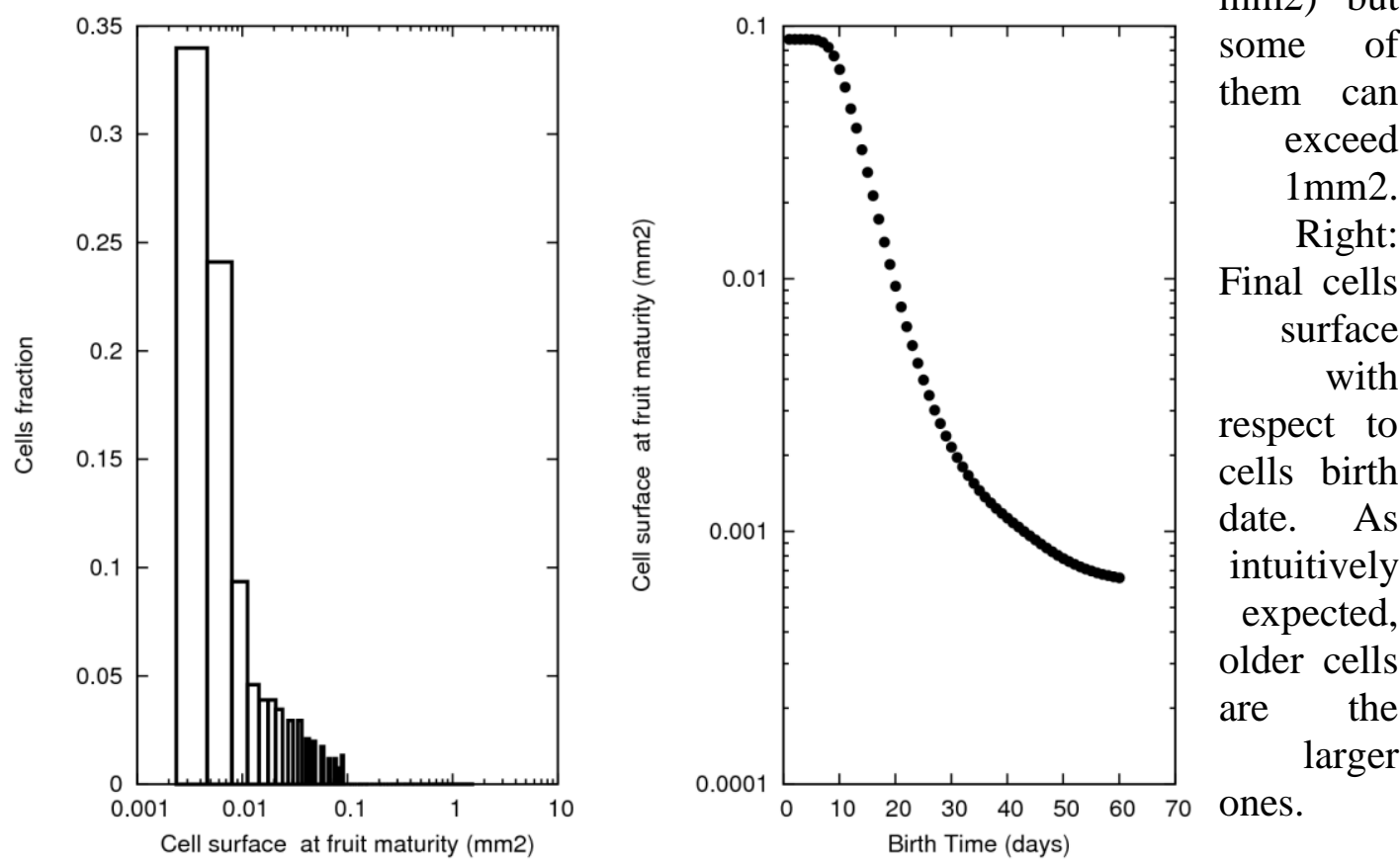

Figure 3: Cells distribution at fruit maturity under water-stressed conditions.

Left: Cells distribution is shrunk with respect to the normal case. Right: Water stress does not affect all cells equally and cells surface is not simply a monotonic decreasing function of cells age. 
Version définitive du manuscrit publiée dans / Final version of the manuscript published in :

Acta Horticulturae (2012), Vol. 957, p. 191-196

4. International Symposium on Models for Plant Growth, Environmental Control and Farm Management in Protected Cultivation (HortiModel), Nov 04-08 2012, Nanjing China
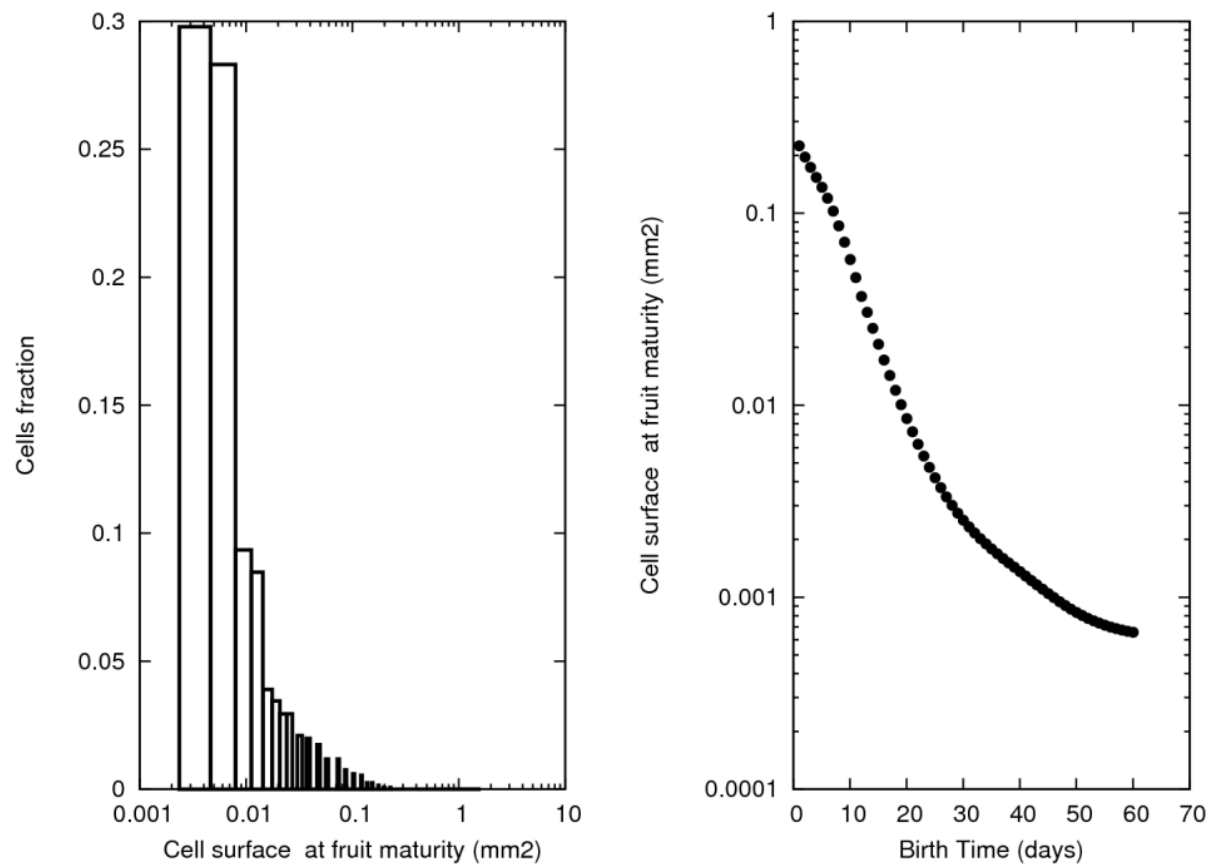

Figure 4: Cells distribution at fruit maturity under water-stressed conditions. Carbon stress does not affect the overall shape of the distribution. 